Journal of the Rubber Research Institute of Sri Lanka (2019) 99, 1-13

\title{
Livelihood capital improvements in the rubber growing community of the Eastern Province of Sri Lanka
}

\author{
E S Munasinghe*, V H L Rodrigo*, P M M Jayathilake*, N M Piyasena* and \\ S M M Iqbal** \\ * Rubber Research Institute of Sri Lanka, Dartonfield, Agalawatta, Sri Lanka \\ ** 12/25, Sinhapura Road, Chilaw, Sri Lanka
}

\begin{abstract}
Rubber cultivation in Sri Lanka has recently been expanded to the Eastern Province. With an initial observation on the positive effects of this process on the rural community in this region, the present study was conducted to either characterize or quantify the impacts of rubber cultivation on the rural community assessing the livelihood capital assets, i.e. Human, Physical, Natural, Financial and Social aspects. Padiyathalawa Divisional Secretaries area of the Eastern Province with a reasonable number of rubber lands under harvesting was selected for the study. All farmers having mature rubber fields (33) were assessed together with similar number of non-rubber farmers of the same village for comparison. Both types of farmers were in the range of 40-60 years of age and educated up to secondary level in the local school. All had no other occupation than farming and having an average of four members in a family and all had sufficient family labour for on-farm activities. With the additional income generated from rubber, a higher level of Financial capital was observed among rubber farmers. As a result, expenditure of rubber farmers was $40 \%$ higher than the rest and its pattern showed that rubber farmers spend more on children's education, family health and charity gaining a higher level of Human capital. Rubber cultivation has not so far influenced the Natural capital since all farmers had equal opportunities in accessing water sources and lands with fertile soils. Further, rubber associated development in Physical capital has made farmers to have basic infrastructure facilities for their houses, some luxury appliances for convenience, facilities to strengthen social connectivity and improvement in farming. With more social interactions, Social capital was found to be higher among rubber farmers. All these findings confirmed the suitability of rubber cultivation as a livelihood improvement strategy in rural development programmes in the Eastern province of Sri Lanka.
\end{abstract}

Key words: non traditional areas, rubber cultivation, social impact

\section{Introduction}

Rubber industry plays an imperative role in Sri Lankan economy by contributing $0.3 \%$ to the Gross Domestic Production
(Anon, 2016a). To cater the future demand for raw rubber, the Rubber Industry Master Plan (RIMP) expects to widen the production base to yield over 
175,000 MT per year by 2020 (Anon, 2015). However, records in 2016 show that the country had produced only 79,100 MT of raw rubber from existing 132,700 hectares of which $90 \%$ is concentrated in traditional Wet Zone (Anon, 2016b). Being closer to the metropolitan areas, lands in Wet Zone are highly subjected to fragmentation for settlements and other more lucrative economic ventures, threatening the existing cultivation and rubber cultivations planned for the future. Therefore as mentioned in RIMP, focus is given to cultivate rubber in nontraditional areas of the country, where ample arable land is available.

Being a war-torn area neglected for nearly three decades, Eastern province has been targeted for development programmes by the Government of Sri Lanka (GoSL). It comprises large extent of sparsely populated lands indicating the potential for establishing plantation crops like rubber. Population density in Eastern province is 176 persons $/ \mathrm{km}^{2}$ and $26 \%$ of agricultural lands in the country are in this region. Also, more women in the region are unemployed with an unemployment rate of $5.5 \%$ (Anon, 2016a). Farmers in these areas mainly depend on rain-fed subsistence farming and the majority are either below or hovering on the poverty line (Anon, 2011). Having high land per capita and labour force, GoSL has launched a high priority rubber planting programme in this region providing additional inputs with a target of 10,000 ha (Rodrigo and Iqbal, 2006). Rubber was firstly introduced to a village in Padiyathalawa Divisional Secretariat area of Ampara
District in Eastern Province in 2003 and latex harvesting began in 2011.

Importance of assessing the impact of newly introduced cropping system on livelihood of a community has been well explained (Nath and Inoue, 2009; Rist et al., 2010; Scoones, 1998) and methodologies have been developed to assess such impacts through household assets (Ashley and Hussein, 2000; Scoones, 2009; Toillier et al., 2011). Accordingly, some studies have been conducted elsewhere to explore the impact of rubber cultivation on rural livelihood (Fu et al., 2009; Longpichai et al., 2012; Viswanathan and Shivakoti, 2006). They have confirmed that rubber cultivation can affect the household assets of rural livelihood in different perspectives depending on community characteristics. Enhancement of rural livelihood due to existing rubber cultivation has been documented in Sri Lankan context comparing with the scenarios of some other rubber growing countries (Nath et al., 2013). In addition, importance of cultivating rubber with some other crops and livestock as integrated farming systems to make farmers more profitable has been discussed (Munasinghe and Rodrigo, 2004; Rodrigo et al., 2001; Somboonuske, 2001; Viswanathan and Shivakoti, 2008). Prospects of expanding rubber cultivation to non-traditional areas in South-East Asia have been investigated by Fox et al. (2011) and Fox and Castella (2013) both in socioeconomic and environmental terms. On the other hand, evaluation of the biodiversity and socio-economic risks of land conversion to rubber plantations has 
E S Munasinghe et al.

also been considered (Ahrends et al., 2015). Further, importance of stakeholder perception on rubber cultivation programmes have also been emphasized (Fischer and Vasseur, 2002; Wigboldus et al., 2017).

To date, 1,750 ha of rubber have been cultivated in Eastern Province with $c a$. 2,500 smallholders and 32 holdings (17 ha) have reached the stage of latex harvesting (Anon, 2017). Arrangements are in the way to provide especial subsidy programmes (about 33\% higher monitory value over the usual programme) with international funding to promote rubber based farming systems in this region. In addition to the improvement of rural livelihood providing a continuous permanent income source, increasing the rubber production in the country and sustain the environment through enhancing the tree cover are also expected in this effort.

Initial studies conducted so far to explore the benefits of rubber cultivation in the Eastern province of Sri Lanka have given an indication of significant positive impact on rural livelihood (Rodrigo et al., 2009; Rodrigo et al., 2014). However detailed investigations are required to identify the contribution of rubber cultivation on wellbeing of the rural community in the Eastern province of Sri Lanka.

This study aimed to characterize and quantify the impact of rubber cultivation on the community in the Eastern province through the assessments on major livelihood assets in terms of Human, Physical, Natural, Financial and Social capital.

\section{Methodology}

The study was conducted in Padiyathalawa Divisional Secretariat area of Ampara District where rubber was initially introduced in the Eastern Province of Sri Lanka (IL2). Farmers having mature rubber (rubber fields with latex harvesting) were the main target group. As total number of farmers having mature rubber fields had been limited to 33 , total population was selected for the study. For the purpose of comparison, 34 out of 107 fulltime farmers who had not cultivated rubber in the same village were selected on random basis.

The study was conducted during the period of January to August 2017. Initially, an awareness programme was conducted to make the relevant farmers aware of the objectives and general methodology of the intended study. Thereafter, interviewer administered questionnaire was conducted for data gathering. Thereafter, interviews with farmers were held using the local language (Sinhala) for gathering required information. Livelihood status of both rubber and non-rubber farmers was assessed in terms of Human, Physical, Social, Natural and Financial capital assets. In building up the Human capital, farmers' age, gender, education level, literacy, occupation and details of the family such as labour force, number of dependents and expenditure pattern of the household were considered. Prevalence of natural resource stocks such as water source and access to land and quality of the lands were considered as Natural capital assets. Under the Physical capital assets basic 
infrastructure of house (type of floor, wall, roof and sanitary facilities), convenience in dwelling (furniture and electrical appliances, electricity and water supply to house, energy source for cooking), connectivity with the society (telecommunication, access road and road vehicle) and improvement in farming (livestock, farm vehicles and farm equipment) were considered. Borrowing and lending power of money, involvement in religious activities and charity, participation and leadership in community activities, interaction with relations and friends were considered as Social capital assets. Financial capital assets were determined by household income and securities (safe keepings).

Both descriptive and quantitative methods were used to analyze the data. To assess the significance in comparing capital assets between rubber and non rubber farmers, t-tests were made. All analyses were performed using GENSTAT ver. 19 statistical package (VSN International, 2017).

\section{Results \\ Importance of human capital of farmers}

The majority of households were maleheaded (94\%) with an average family size of four including one dependent. The age of farmers varied between 26 to 78 ; however, $70 \%$ lied in the range of 4060 years. Most of the farmers had secondary level education with that $80 \%$ are literate on both read and write ability. None of them had experience in doing other occupations except farming. All families were enriched with own family labour having an average of 18 working hours per day per family.
Total average annual household expenditure of a rubber growing family (LKR 81,717) was significantly higher $(\mathrm{t}=-3.22, \mathrm{p}<0.05)$ than that of a nonrubber growing family (LKR 56,503). Among the components of expenditure, greater portions have been recorded in cultivating crops and food for household in both types of households. In percentage apportion, expenditure on food of both groups was more or less similar with $34 \%$ share to the total. However in absolute terms, rubber farmers have spent LKR 27,000 per annum for their food whilst that of nonrubber farmers was LKR 19,000. Rubber farmers have assigned significantly higher proportion (each $5 \%$ ) of their expenditure for children's education ( $\mathrm{t}=-$ $3.43, \mathrm{p}<0.05)$ and family health care $(\mathrm{t}=-$ $3.15, \mathrm{p}<0.05)$ than non-rubber farmers (Fig. 1).

Importance of natural capital of farmers

Natural capital assets such as prevalence of water source, access to land and quality of the land did not show significant difference among both farmer groups. All farmers have had safe water sources; wells for drinking water and water streams for their daily other needs. Lands were mostly uniform and enriched with soil properties. Irrespective of the farmer group, the average lands owned by a farmer was 2 ha and many of those lands are located within $1 \mathrm{~km}$ distance from the home. Non rubber farmers fully utilize their lands for subsistence farming whilst rubber farmers used only ca. $20 \%$ of that for the same (Fig. 2). 


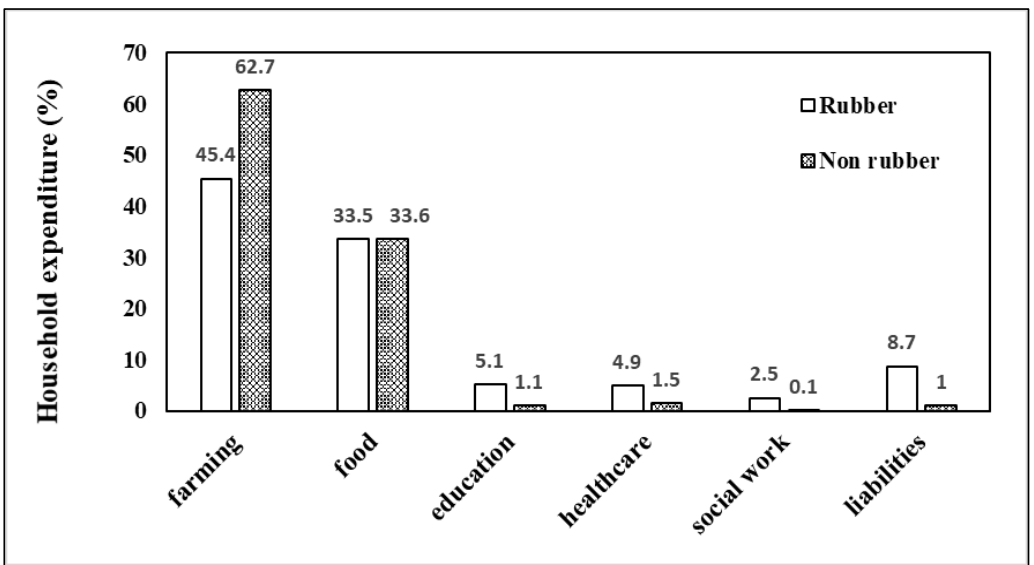

Fig. 1. Household expenditure pattern of farmers

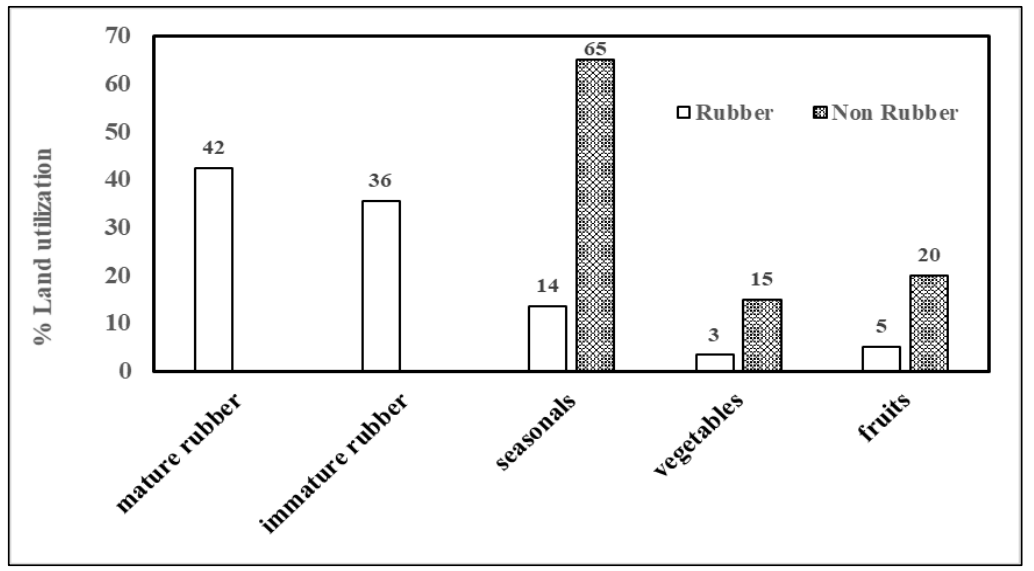

Fig. 2. Land distribution for different crops

\section{Importance of financial capital of farmers}

Total household income of a rubber farmer comprising both farm and offfarm earnings was significantly ( $t=-5.40$, $\mathrm{p}<0.05)$ higher than that of non- rubber farmer. Annual income of a rubber cultivating household ranged from LKR 100,000 to LKR 555,000 with an average of LKR 280,000. Further, the income from rubber has accounted for $60 \%$ to the total. However, average income of a nonrubber household has limited to LKR 155,000 and varied within the range of LKR 71,000 to 300,000 (Fig. 3). Rubber farmers have inclined to save money with savings accounts at rural banks and an incident of enrolling in an insurance scheme was recorded by one farmer. 
The average annual saving of a rubber farmer was LKR 12,000.

\section{Importance of Physical capital of farmers}

Having basic infrastructure in rubber growers' houses i.e. cement floor and wall, tile or asbestos roof was significantly higher than that of nonrubber growers. Also, convenience in dwelling such as having electricity and water supply to house, gas/electricity for cooking, luxury furniture and electrical appliances was significantly high among rubber growers. Further, they were significantly enriched with telecommunication facilities and gravel/concrete access roads facilitating connectivity with the society. In addition, rubber farmers have shown significant improvements in purchasing farm vehicles and farm machinery (Table 1 \& Fig. 4).

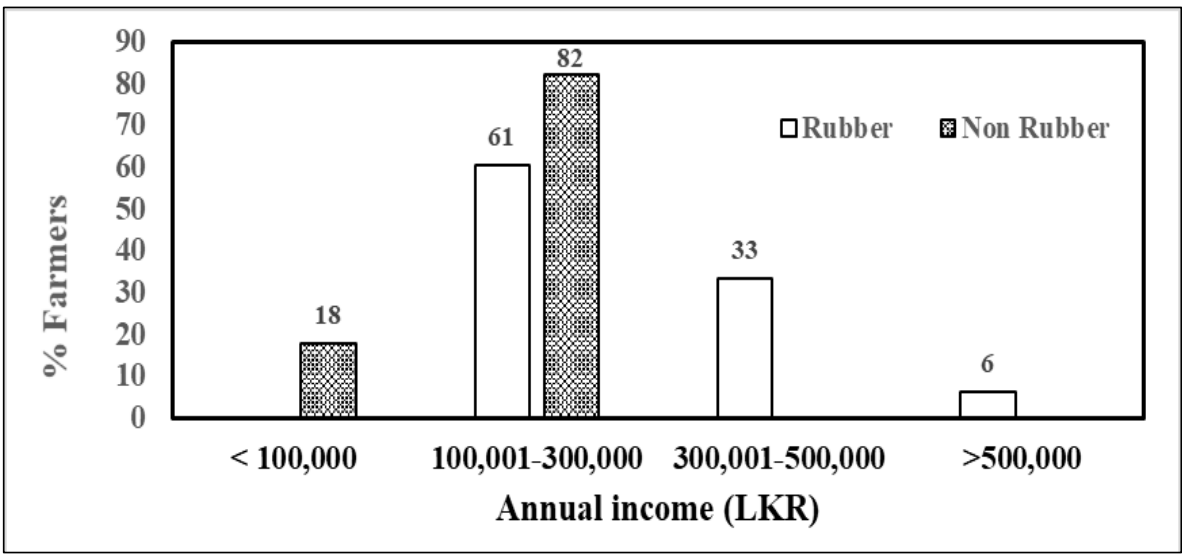

Fig. 3. Annual income distribution of households

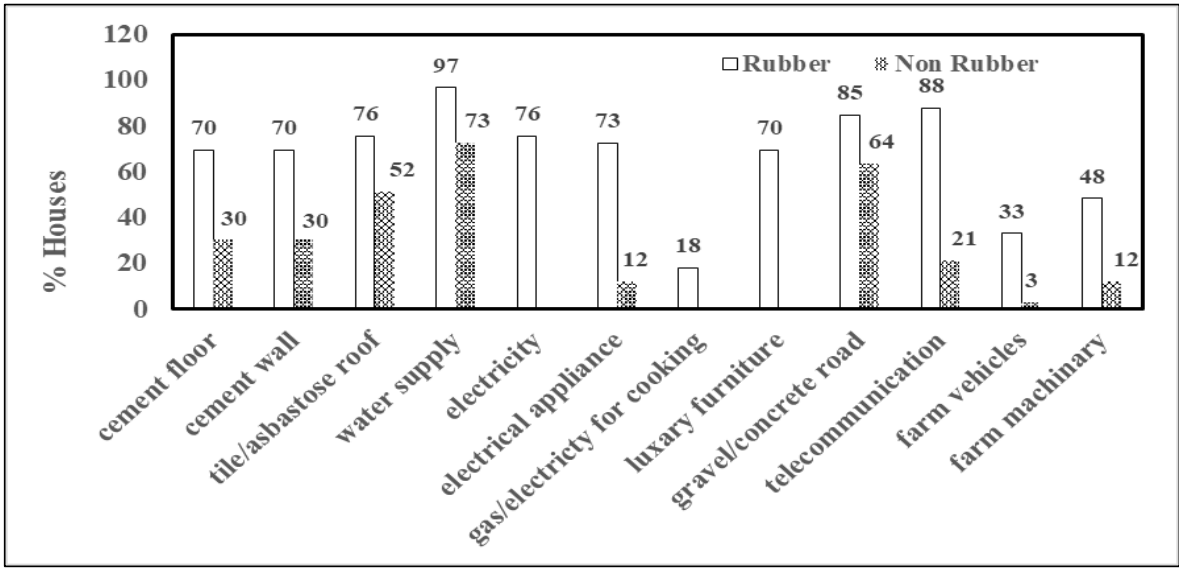

Fig. 4. Physical properties of farmer houses 
E S Munasinghe et al.

Table 1. Statistical significance in the impact of rubber cultivation on physical assets of rubber farmers

\begin{tabular}{lcrr}
\hline Physical capital & Spearman rank correlation & t approximation & P>[t] \\
\hline Basic infrastructure; & & & \\
Cement floor & 0.403 & 3.55 & $<0.001$ \\
Cement wall & 0.403 & 3.56 & $<0.001$ \\
Tile/Asbestos roof & 0.266 & 2.23 & 0.029 \\
Sanitary facilities & 0.222 & 1.84 & 0.070 \\
Convenience in dwelling; & & & \\
Water supply & 0.356 & 3.07 & 0.003 \\
Electricity & 0.783 & 10.15 & $<0.001$ \\
Electrical appliances & 0.618 & 6.34 & $<0.001$ \\
Gas/electricity for & 0.318 & 2.71 & 0.009 \\
cooking & & & \\
Furniture & 0.734 & & \\
Connectivity with society; & & & \\
Gravel/concrete access & 0.260 & & \\
road & & & \\
Tele-communication & 0.675 & & 0.033 \\
Road vehicles & 0.073 & 7.37 & $<0.001$ \\
Improvement in farming; & & 0.59 & 0.556 \\
Farm vehicles & 0.396 & & \\
Farm machinery & 0.401 & 3.48 & $<0.001$ \\
Livestock & 0.043 & 3.53 & $<0.001$ \\
& & 0.34 & 0.732 \\
\hline
\end{tabular}

Importance of social capital of farmers Rubber farmers have significantly high capacity over non rubber farmers in lending money to neighboring farmers in the village. Further, it was observed that interaction with relatives and friends and involvement in religious activities have increased significantly with the rubber cultivation. Also, they contributed significantly high amount for charity work and spent much time for community participation (Table $2 \&$ Fig. $5)$.

Table 2. Statistical significance in impact of rubber cultivation on social capital of rubber farmers

\begin{tabular}{lrrr}
\hline & Spearman rank correlation & t approximation & $\mathbf{P}>[\mathbf{t}]$ \\
\hline Money lending capacity & 0.672 & 7.32 & $<0.001$ \\
Money borrowing capacity & 0.018 & 0.15 & 0.884 \\
Visit relatives & 0.390 & 3.41 & 0.001 \\
Visit friends & 0.408 & 4.23 & $<0.001$ \\
Visit religious places & 0.465 & 0.600 & $<0.001$ \\
Community participation & 0.034 & 2.58 & 0.012 \\
Community leadership & 0.205 & 1.69 & 0.095 \\
Charity work & 0.861 & 13.63 & $<0.001$ \\
\hline
\end{tabular}




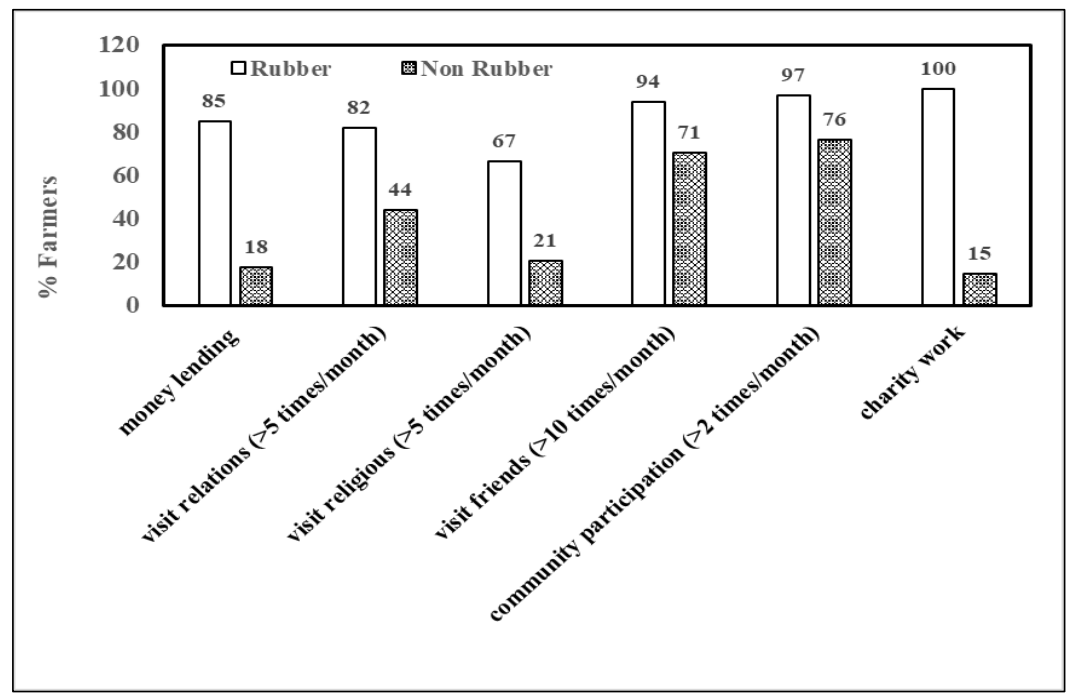

Fig. 5. Social capabilities of farmers

\section{Discussion}

In the promotion process of rubber cultivation in non-traditional areas, rainfed farming systems are the focus in Sri Lanka and elsewhere (Fox et al., 2008; 2011; Fox and Castella, 2013). In such systems, farmers are usually engaged in subsistence agriculture which provides directly the most of dietary needs and then, the sale of additional produce facilitates to meet the other requirements. Uncertainty in weather pattern makes the rural life indecisive resulting in hidden poverty. For instance, $8 \%$ of farmers in the Eastern Province in Sri Lanka are considered to be poor hence receive the social benefits given to the poor by the government (e.g. Samurdhi payment). In addition to the rubber production, the promotion of rubber cultivation in such areas aims at providing a permanent income source to the poor for their livelihood improvements (Anon, 2015) which was the focal point in the present study.

A previous study conducted in the same village at the time of introducing rubber showed that farmers in the village were having more or less equal living standards (Rodrigo et al., 2009). Further, there were no records on any new introduction of income generating activities to the village. Therefore, it is very clear that the significant increase in Financial assets of farmers is due to the income from rubber. Similar financial improvements in farming communities have been observed in traditional rubber growing areas in Sri Lanka, India and Thailand (Nath et al., 2013; Viswanathan, 2008; Viswanathan and Shivakoti, 2006; 2008). As a result, the bargaining power has improved as shown by the changes in Human capital where rubber farmers were able to spend $40 \%$ more over the non-rubber farmers. 
In existence, being an essential item, dietary needs are met first before spending on other necessities. With the increase in income level, the absolute amount spent for food has increased among rubber farmers, however proportion to the total was basically same between two categories of farmers. It shows that food habit of farmers has changed marginally with additional income from rubber, but still they are confined to a simple lifestyle. Sri Lanka is among the countries in the lower middle income category with the records on close to zero hunger (Anon, 2014) and this study provides evidence of achieving development goals.

Dealing with banks and insurance companies with some level of savings by rubber farmers indicates the changes in social dynamics of farmers towards sustainable and less risk future. Additional expenditure has been incurred on cultivation of crops which can be considered as a short- and medium-term investment. Moreover, in building up Human capital, more attention has been given for long-term investments for sustainable future such as own and family health care and more importantly, children's education. Sri Lanka has a fairly good free medical system (Rannan-Eliya et al., 2015); however in handing a large number of patients, such facilities seem inadequate to the level of satisfaction required by people. Time taken to meet a doctor and have it at convenient time, obtaining special care when necessary, distance travel and inadequate drug supply are reported as some of weaknesses in the free medical system. Therefore, if finances are available, people in Sri Lanka tend to go for private medical assistance. However, with poor income in subsistence farming under rain-fed systems, it seems more farmers have to forego even the health care to some extent and depend mainly on the government assisted free medical facilities. Also, despite the free education in Sri Lanka for children, the competition for exam success has resulted in seeking private tuition for difficult subjects. Additional finance given by rubber has opened the door for this facility bringing some hope to a brighter future for farmers' children.

Natural Assets are dominated by lands and then, water availability. Therefore, in short-term, improvements in this category cannot be expected since all farmers have a reasonable extent ( $c a .2$ ha) of lands and in general, individuals in the farming do not prefer to sell their lands others as everyone needs to depend on lands for subsistence. Any additional acquisition should be made from the Government lands. Though water is in scarce during dry periods, investing on water cannot easily be done at individual level as it requires community involvements. With only a few rubber growing farmers, such moves cannot be expected and it may be a reality only happens with a well organized rubber farming community.

Improvement in Physical assets such as upgrading the condition of the house to be more attractive, convenient (e.g. electricity, water supply, electric appliances and furniture) and stable (e.g. cement walls and floor, asbestos/tile roof) reflects the changes in living 
standards of farmers associated with rubber cultivation. These facts are consistent with the findings of Nath and Inoue (2009) and Nath et al. (2013). Although such facilities are essential components in today's context, the study reveals the level of substandard life of farmers in this region. The majority is living on farming under rain-fed agriculture and no guarantee is available to provide stable income for the peasant community. Instead of maintaining positive cash flow towards the Government for the development of the country, the Government has to pump money back as aids and reliefs to sustain the rural life in these areas. Therefore, promotion of rubber cultivation in these areas creates a win-win situation where the Government can develop the rubber industry by supporting the poor.

Long-term positive impact of rubber cultivation to the national economy will also be shown by the changes in Social Assets. Improvement in lending capability of money shows the rubber farmers' financial strength. More economic returns can be expected in long-term by investing those money. Enhancements in the interactions with relations and fellow villagers of rubber farmers, their participation in community activities and involvement in more charity works will also add an unseen social value to the rural economy in the socioeconomic context.

Findings of this study basically show the positive impacts of rubber cultivation on the economies at household, village and country levels whilst no negative impacts recorded. Therefore, it justifies the efforts and investments made to expand the rubber cultivation in the area for the enhancement of rural livelihood. In refining a production system for improved sustainability, the modern management tools such as material flow and material flow cost analyses and lifecycle assessment can be deployed. Such approaches have been adopted in raw rubber manufacturing (Duniwilla $e t$ al., 2017). No such studies have ever been conducted for rubber cultivation and hence proposed for future research.

\section{Conclusions}

Rubber cultivation in the Eastern province has been able to improve the Human capital of farmers showing significant increase in the expenditure on children's education and family health care. Increase in total household income resulted in an improvement of Financial capital with more rubber farmers in high income categories. Further, rubber associated development in Physical capital has made farmers to have basic infrastructure facilities for their houses, some luxury appliances for convenience, facilities to strengthen social connectivity and improvement in farming. Capacity of lending money, visiting relations and friends, attending to religious activities, participating community activities and charity work were higher in rubber farmers showing the improvement in Social capital. Therefore, the study confirmed the utility values of rubber cultivation in improving the overall livelihood of peasant community in the Eastern Province of Sri Lanka. 


\section{Acknowledgements}

We acknowledge the facilities given by the Rubber Research Institute of Sri Lanka (RRISL) to conduct this research activity. Also, appreciate the advice given on data analyses by Dr. Wasana Wijesuriya of RRISL and Dr. Sisira Kumara of University of Sri Jayewardenepura, Sri Lanka. Moreover, the cooperation given by the farmers in Padiyathalawa village in collecting information is greatly appreciated. Further, acknowledgement is extended to the "Australia Awards Fellowships Program for Sri Lanka - 2017" funded by the Department of Foreign Affairs and Trade, Australia, and co-hosted by Monash University, Australia and the Sri Lanka Institute of Development Administration for the guidance given to the Principal Investigator.

\section{References}

Ahrends, A, Hollingsworth, P M, Ziegler, A D, Fox, J M, Chen, H, Su, Y and $\mathrm{Xu}, \mathrm{J}$ (2015). Current trends of rubber plantation expansion may threaten biodiversity and livelihoods. Global Environmental Change 34, 48-58.

Anon (2011). Statistical Abstract 2011. Department of Census \& Statistics, Sri Lanka. Colombo, Sri Lanka.

Anon (2014). Millennium Development Goals Country Report Sri Lanka 2014. United Nations, Sri Lanka, ISBN 978-9557622-00-2.

Anon (2015). Sri Lanka Rubber Industry Master Plan 2015-2024. A National Agenda for Rubber Industry Development. Ministry of Plantation Industries, Colombo, Sri Lanka.

Anon (2016a). Annual Report 2016. Central Bank of Sri Lanka, Colombo, Sri Lanka.
Anon (2016b). Statistical Information on Plantation Crops. Ministry of Plantation Industries, Colombo, Sri Lanka.

Anon (2017). Subsidy Scheme for Rubber Replanting and New Planting. Rubber Development Department, Ministry of Plantation Industries, Colombo, Sri Lanka.

Ashley, C and Hussein, K (2000). Developing methodologies for livelihood impact assessment: experience of the African Wildlife Foundation in East Africa. Working Paper 129. London, UK: Overseas Development Institute.

Dunuwila, P, Rodrigo, V H L and Goto, N (2017). Financial and Environmental Sustainability in Manufacturing of Crepe Rubber in terms of Material Flow Analysis. Material Flow Cost Accounting and Life Cycle Assessment. Journel Clean. Prod., 2017 (submitted for publication).

Fischer, A and Vasseur, L (2002). Smallholder perceptions of agroforestry projects in Panama. Agroforestry Systems 54,103-113.

Fox, J and Castella, J C (2013). Expansion of rubber (Hevea brasiliensis) in Mainland Southeast Asia: What are the prospects for smallholders? Journal of Peasant Studies 40(1), 155-170.

Fox, J, Castella, J C and Ziegler, A D (2011). Swidden, rubber and carbon: Can REDD work for people and the environment in montane mainland Southeast Asia? CCAFS Working Paper No. 9. Denmark, Copenhagen: CGIAR Research Program on Climate Change, Agriculture and Food Security (CCAFS).

Fox, J, McMahon, D, Poffenberger, $\mathrm{M}$ and Vogler, J (2008). Land for my grandchildren: Land use and tenure change in ratanakiri: 1989-2007. Phnom Penh, Cambodia: Community Forestry International.

$\mathrm{Fu}, \mathrm{Y}$, Brookfield, H, Guo, H, Chen, J, Chen, A and Cui, J (2009). Smallholder rubber 
Livelihood capital of rubber growing community

plantation expansion and its impact on local livelihoods, land use and agrobiodiversity, a case study from Daka, Xishuangbanna, Southwestern China. International Journal of Sustainable Development \& World Ecology 16, 22-29.

Longpichai, O, Perret, S R and Shivakoti, G $P$ (2012). Role of livelihood capital in shaping the farming strategies and outcomes of smallholder rubber producers in southern Thailand. Outlook on Agriculture 41(2), 117-124. doi: 10. 5367/oa.2012.0085.

Munasinghe, E S and Rodrigo, V H L (2004). Can rubber (Hevea brasiliensis Muell. Arg.) be grown as a timber crop? Bulletin of Rubber Research Institute of Sri Lanka 47, 34-39.

Nath, T K and Inoue, M (2009). Forest-based settlement project and its impacts on community livelihood in the Chittagong Hill Tracts, Bangladesh. The International Forestry Review, Commonwealth Forestry Association. 11:3. 394-407.

Nath, T K, Inoue, M and Zoysa, M De (2013). Small-scale rubber planting for enhancement of people's livelihoods: A comparative study in three South Asian Countries. International Journal of Sustainable Development and World Ecology 16 (1), 22-29.

Rannan-Eliya, R P, Wijemanne, N, Liyanage, I K, Jayanthan, J, Dalpatadu, S, Amarasinghe, S and Anuranga, C (2015). The quality of outpatient primary care in public and private sectors in Sri LankaHow well do patient perceptions match reality and what are the implications? Health Policy and Planning 30, 59-74.

Rist, L, Feintrenie, L and Leva, P (2010). The livelihood impacts of oil palm: smallholders in Indonesia. Biodiversity Conservation. 19:1009-1024. DOI 10. 1007/s10531-010-9815-z.

Rodrigo, V H L, Iqbal, S M M and Munasinghe, E S (2009). Rural livelihood and rubber cultivation in Eastern province of Sri Lanka. Journal of the Rubber Research Institute of Sri Lanka 89, 58-69.

Rodrigo, V H L, Iqbal, S M M, Munasinghe, E S and Balasooriya, B M D C (2014). Rubber in east assures the perceived benefits; increased rubber production, amelioration of the climate and improved the rural livelihood. Journal of the Rubber Research Institute of Sri Lanka 94, 33-42.

Rodrigo, V H L and Iqbal, S M M (2006). Rubber (Hevea brasiliensis Muell. Arg.) cultivation in the Eastern Province of Sri Lanka with alleviation of rural poverty and increase in the forest cover: a feasibility study. International Conference on Humid Tropical Ecosystems: Changes, Challenges, Opportunities. December 2006, Kandy, Sri Lanka. 72.

Rodrigo, V H L, Thennakoon, S and Stirling, C M (2001). Priorities and objectives of smallholder rubber growers and the contribution of intercropping to livelihood strategies: a case study from Sri Lanka. Outlook on Agriculture 30(4), 261-266.

Scoones, I (1998). Sustainable rural livelihoods: A framework for analysis. Working Paper 72. Brighton, UK: Institute of Development Studies.

Scoones, I (2009). Livelihoods perspectives and rural development. Journal of Peasant Studies 36(1), 171-196.

Somboonuske, B (2001). Recent evolution of rubber-based farming systems in Southern Thailand. Kasetsart Journal (Social Sci.) 22, 61-74.

Toillier, A, Serpantie, G, Herve, D and Lardon, S (2011). Livelihood strategies and land use changes in response to conservation: Pitfalls of community-based forest management in Madagascar. Journal of Sustainable Forestry 30(1-2), 20-56.

Viswanathan, P K (2008). Emerging smallholder rubber farming systems in India and Thailand: A comparative 
E S Munasinghe et al.

economic analysis. Asian Journal of Agriculture and Development, Number 2, Vol. 5.

Viswanathan, P K and Shivakoti, G P (2006). Economic integration of tribal societies in the post-reforms era: Perspectives on rubber-based farming systems in North East India. North East India Stud. 1(2), 80106.

Viswanathan, P K and Shivakoti, G P (2008). Adoption of rubber-integrated farmlivelihood systems: contrasting empirical evidence from the Indian context. Journal of Forest Research 13, 1-14, DOI: 10.1007/s10310-007-0047-3.
VSN International (2017). Genstat for Windows. $19^{\text {th }}$ ed. Hemel Hempstead, UK: VSN International; 2017.

Wigboldus, S, Hammond, J, Xu, J, Yi, Z, He, J, Klerkx, L and Leeuwis, C (2017). Scaling green rubber cultivation in Southwest China -An integrative analysis of stakeholder perspectives. Science of the Total Environment 580, 1475-1482.

Address for correspondence: $\mathrm{Dr}$ (Mrs) E S Munasinghe, Principal Research Officer, Adaptive Research Unit, Rubber Research Institute of Sri Lanka, Dartonfield, Agalawatta, Sri Lanka, e-mail: enokamunasinghe@yahoo.com 